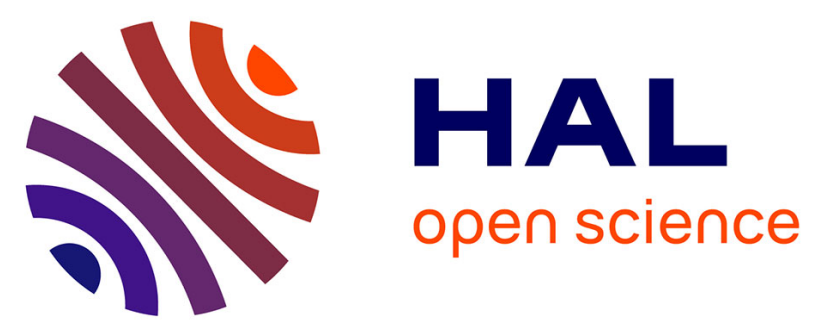

\title{
Influence of regions, land uses and soil properties on termite and ant communities in agricultural landscapes of the Colombian Llanos
}

Catalina Sanabria, Florence Dubs, Patrick Lavelle, Steven J. Fonte, Sébastien Barot

\section{To cite this version:}

Catalina Sanabria, Florence Dubs, Patrick Lavelle, Steven J. Fonte, Sébastien Barot. Influence of regions, land uses and soil properties on termite and ant communities in agricultural landscapes of the Colombian Llanos. European Journal of Soil Biology, 2016, 74, pp.81-92. 10.1016/j.ejsobi.2016.03.008 . hal-01303702

\section{HAL Id: hal-01303702 \\ https://hal.sorbonne-universite.fr/hal-01303702}

Submitted on 18 Apr 2016

HAL is a multi-disciplinary open access archive for the deposit and dissemination of scientific research documents, whether they are published or not. The documents may come from teaching and research institutions in France or abroad, or from public or private research centers.
L'archive ouverte pluridisciplinaire HAL, est destinée au dépôt et à la diffusion de documents scientifiques de niveau recherche, publiés ou non, émanant des établissements d'enseignement et de recherche français ou étrangers, des laboratoires publics ou privés. 


\title{
Influence of Regions, Land Uses and Soil Properties on Termite and Ant Communities in Agricultural Landscapes of the Colombian Llanos
}

\author{
Catalina Sanabria \\ UPMC, IEES-Paris. UPMC, 7, quai St Bernard, 75005. Paris, France. \\ International Center for Tropical Agriculture (CIAT), Km 17 via Cali-Palmira - Colombia. \\ catasanabria@gmail.com
}

Florence Dubs

IRD, IEES-Paris. IRD, 32, avenue Henri Varagnat, 93143 Bondy cedex, France.

florence.dubs@ird.fr

Patrick Lavelle

International Center for Tropical Agriculture (CIAT), Km 17 via Cali-Palmira - Colombia. UPMC, IEES-Paris. UPMC, 7 quai St Bernard, 75005 Paris, France

patricklavelle@ird.fr

Steven J. Fonte

Department of Soil and Crop Sciences, Colorado State University, Fort Collins, CO 80523, USA.

International Center for Tropical Agriculture (CIAT), Km 17 via Cali-Palmira - Colombia.

stevenfonte@gmail.com

Sébastien Barot

IRD, IEES-Paris. UPMC, 7, quai St Bernard, 75005 Paris, France.

sebastien.barot@ird.fr

\begin{abstract}
Ants and termites, as soil engineers, provide many ecosystem services that can be important for the sustainability of agriculture. The aim of this study was to evaluate the impact of land use on ant and termite communities in Colombian savanna landscapes, and to assess whether this impact is associated with the modification of soil physical and chemical properties. Ants and termites were sampled in five different agricultural and semi-natural systems across three regions of the
\end{abstract}


eastern Colombian Llanos: 1) annual crops (maize, soy and rice), 2) rubber plantations, 3) oil palm plantations, 4) improved pastures and 5) semi-natural savannas. A total of 91 ant and 16 termite species were collected. Multivariate analysis revealed that termite communities significantly differed among land uses, but not between regions. Ant communities differed between regions and land uses. Based on between group analyses of termite communities, three groups of land use can be distinguished: one formed by semi-natural savannas and improved pastures, the second by oil palm plantations and annual crops and the third by rubber plantations. General linear models applied separately to each species found 19 significant associations of soil physical or chemical properties, land uses or regions with 15 ant species and 14 significant associations with 6 termite species. Taken together, there is a strong association between land use and ant or termite communities and this influence is likely due to changes in ant and termite habitats resulting from agricultural practices such as tillage, fertilization, and lime addition. These results suggest that annual crops are the most detrimental land use for termites and ants, because their communities are highly sensitive to vegetation cover and agricultural practices such as tillage. Maintaining a high diversity of soil engineers and the ecosystem services they provide

likely depends on the maintenance of natural ecosystems in the landscape and the adoption of practices that reduce impacts on soil ecosystem engineers when native ecosystems have been transformed into agricultural systems.

Key words: Savannas, oil palm plantations, rubber plantations, perennial crops, annual crops, soil physical and chemical properties, soil ecosystem engineer.

\section{Introduction}

Colombian savannas are part of the second largest savanna system in South America [1]. In these savannas the intensification of land use and high population growth has turned the region into one 
of the most threatened ecosystems in Colombia [2]. Savannas are rapidly being converted from semi-natural systems, dedicated largely to extensive cattle ranching and low-input traditional agriculture, to highly intensified commercial production of annual crops (rice, soybean, maize), biofuels (sugar cane and oil palm) and tree crops such as rubber. It is estimated that over 50,000 ha have been converted over the last two decades and recent trends show this agricultural expansion to be rapidly accelerating [2].

Soil is considered to be one of the most diverse and least understood reservoirs of biodiversity in the biosphere [3]. Threats to this biodiversity are a source of concern for the intrinsic value of biodiversity, but also because soil fauna provide many ecosystem services [4]. The functions performed by soil biota have large, direct and indirect effects on crop growth and quality, soil and residue-borne pests, disease incidence, nutrient cycling and water transfer and the overall sustainability of agroecosystems. They also influence the resistance and resilience of agroecosystems to abiotic disturbance and stress [5]. This study focuses on termites and ants, recognized as important soil engineers. Ecosystem engineers directly or indirectly modulate the availability of resources to other species, by causing physical, biological and chemical changes in the properties of their environment [6], which potentially influences all organisms sharing the same environment. Typically, soil ecosystem engineers modify and in some instances may determine the major physical, chemical and microbiological properties of the soil $[7,8,9,10,11]$, especially those associated with soil aggregate stability and fertility [10, 12]. As social insects with high abundance and biomass [13], and active in nest building and tunneling, termites and ants are hypothesized to deliver a number of services including contribution to organic matter decomposition, nutrient recycling, bioturbation, tilth, porosity and cation exchange capacity [5, $14,15,16]$. In addition, their consumption or manipulation of organic materials creates biogenic 
structures [3] that can be significant components of the soil profile, and as they usually comprise mixtures of clay and organic materials, they exist as microsites for biological transformations [5]. Termites (as prey) [3] and ants (as predators) [17] may also regulate the abundance of other soil organisms, including pests, at several ecological levels $[3,14,16]$.

Direct evidence of the beneficial role of termites and ants in tropical soils is scarce [5], since definitive experiments would necessitate their exclusion, which is difficult or impossible to achieve in the field except by methods that simultaneously destroy ecological structure [18, 19]. However, land use changes such as deforestation and agricultural intensification (including mono-cropping) along with associated habitat fragmentation, are known to have negative impacts on soil macrofauna $[7,9,14,15,19]$. Because many of these changes lead to a rapid decline in fertility or erosion [13] comparison of the fauna across mosaic landscapes and between different land uses and regions provides both an indirect test of the validity of the soil engineer concept and guidance for future management of cropping systems [19, 20, 21].

Depletion of soil macrofauna is partly explained by their physical vulnerability to disturbance, but may also result from changes to soil properties, especially soil chemistry, and/or from the removal or reduction of niche heterogeneity and from severe modifications of microclimates [7, 9, 10, 22]. Examples of impacts on soil fauna are known for tillage, soil properties, microclimate, food availability and pesticide application, both in Colombia and elsewhere $[9,19]$. In the present study land uses sampled are well-defined representing different levels and types of disturbance in regions of the Orinoco river basin, using a standard monolith method. This enabled termites and ants to be co-collected at each sampling point together with soil from the immediately adjacent wall of the monolith pit. The analysis attempted to elucidate the influence of land use on soil properties and on termite and ant communities, and in turn the influence of soil properties on 
these faunal groups. These analyses are complementary to the results of Lavelle et al. [19] and Sanabria et al. [16] that respectively focus on the impact of land use on some soil ecosystem services, and the possibility to use ant as indicators of ecosystem services.

\section{Materials and methods}

\subsection{Study region and sampling design}

The study sites are located in the Altillanura Plana within the Meta Department of eastern Colombia (between $3^{\circ} 55^{\prime} 21^{\prime \prime} \mathrm{N}-71^{\circ} 01^{\prime} 43^{\prime \prime} \mathrm{W}$ and $4^{\circ} 38^{\prime} 07^{\prime \prime} \mathrm{N}-72^{\circ} 53^{\prime} 55^{\prime \prime} \mathrm{W}$ ). This region is at about $200 \mathrm{~m}$ in elevation, has a humid tropical climate with an average annual temperature of 26 ${ }^{\circ} \mathrm{C}$ and rainfall averaging $2500 \mathrm{~mm}$ yr-1, and have a marked dry season between December and March [10]. Sampling was conducted between June and August 2011 along a $200 \mathrm{~km}$ transect extending from Puerto López (PL), Puerto Gaitán (PG) and Carimagua (C) (to the Northeast) and bounded to the North by the Meta River. In total, five land uses were sampled: 1) annual crops (AC) (include together rice, maize and soybeans), 2) rubber plantations (R), 3) oil palm plantations (OP), 4) improved pastures (IP), and 5) semi-natural savannas (S). In each region, 5 replicates of each land use were sampled, this results in a total of 75 sampled fields (5 land uses $\mathrm{x}$ 5 replicates $\mathrm{x} 3$ regions) and because each sampled field contains three sampled points a total of 225 sub-samples were done.

\subsection{Physical and Chemical Soil analyses}

A set of ten soil physical properties were documented (Table 1): volumetric (VM) and gravimetric or soil moisture $(\mathrm{SM})$ content, micro $(<0.03 \mu \mathrm{m}$; MIC), meso $(0.03-3 \mu \mathrm{m}$; MES) and macro (>3 $\mu \mathrm{m}$; MAC) porosity, available water storage capacity (AWC), bulk density (BD), texture: sand (Sa), silt ( $\mathrm{Si})$ and clay $(\mathrm{Cl})$. Only two of the three texture variables were kept in the 
multivariate analyses ( $\mathrm{Sa}$ and $\mathrm{Si}$ ). In addition, sixteen soil chemical properties (Table 1) were measured including, $\mathrm{pH}$, total soil carbon $(\mathrm{C})$ and nitrogen $(\mathrm{N})$ concentrations, cation exchange capacity (CEC), Al saturation ( $\mathrm{SAl}$ ), macro and micronutrient concentrations ( $\mathrm{Ca}, \mathrm{K}, \mathrm{Mg}, \mathrm{P}, \mathrm{Al}$, $\mathrm{S}, \mathrm{B}, \mathrm{Fe}, \mathrm{Mn}, \mathrm{Cu}$ and $\mathrm{Zn}$ ). At each sampling point soil for physical analyses was taken from the vertical walls of the central monolith pit, while soil for chemical analyses was taken from soil excavated from the pit after sorting out macrofauna.

\subsection{Ants and termites biodiversity}

In each sampled field three sampling points were located equidistant along a $400 \mathrm{~m}$ transect. At each sampling point, ants and termites were collected along with other groups of soil macrofauna (only ant and termite results are considered in the present paper) by employing a modified TSBF collection method [23]. Sampling consisted in the excavation, at each sampling point, of a central monolith (25 x $25 \mathrm{~cm} \times 20 \mathrm{~cm}$ deep) and two adjacent monoliths $(25 \mathrm{~cm} \times 25 \mathrm{~cm} \times 10 \mathrm{~cm}$ deep) located $10 \mathrm{~m}$ to the North and South of each central monolith and hand-sorting of all macrofauna from the litter and soil of these three monoliths. Hence, a total of nine soil monoliths were collected for each sampled field. Standing plant biomass was cut 2-3 cm above the soil surface and removed prior to sampling. In the laboratory, ants and termites were separated from other macrofauna organisms and were cleaned and preserved in $96 \%$ alcohol. Identification of ants to the genus level was performed following keys of Palacio and Fernandez [24] and Bolton [25]; keys that are specific for each gender were used for finer level identifications according to AntWeb [20] and Longino (2003) [21]. The identification of termites was carried out with keys of Constantino [26] and Rocha and Cancello [8]. In general, the specimens were identified to species level whenever possible, or alternatively, individuals were separated into morphospecies based on differences of physical characteristics. 


\subsection{Statistical analysis}

From the records of the different species and morphospecies of ants and termites collected in each field (75), a data set was built in which species abundance were replaced by species occurrence (i.e. number of monoliths per field in which the species was found) as is commonly done for ants and termites. Given that they are social insects, a single sample may contain an extreme abundance of a rare species [21]. Thus occurrence data provides reliable information on species presence and relative abundance within a community and can be analyzed using general linear models. The multivariate statistical analyses were run removing species occurring in less than two samples, but this did not change the structure of the data set or the main conclusions. Based on these criteria, 13 out of a total of 60 ant species and 10 termite species were selected for multivariate analysis.

\subsubsection{Between-group analysis}

To analyze the effect of the different regions and land use on soil chemical or physical properties, a between-group multivariate analysis was performed for each factor (region and land use), which provides the best linear combination of variables maximizing between-group variance [27]. These analyses were performed on an initial Principal Component Analysis (PCA) to identify the best linear combination of sub-variables describing the regions (Puerto López (PL), Puerto Gaitán (PG), Carimagua (CAR)) or land uses (annual crops (AC), rubber plantations (R), oil palm plantations (OP), improved pastures (IP), semi-natural savannas (S)) quantifying their respective effect on soil physical or chemical properties. The significance of each explanatory variable (region or land use) was tested using a Monte-Carlo permutation test. A between-group analysis was also performed in order to assess the respective effect of region or land use on ant or termite occurrences using Correspondence Analysis (CA) [27]. 


\subsubsection{Co-inertia analysis}

Co-inertia analyses, a two-table ordination method, were used to analyze the impact of soil properties (physics and chemistry) on ant and termite species occurrence. This involves a simultaneous projection, at the same scale, of the PCA conducted on soil properties and the CA conducted on ant and termite occurrences onto the same co-inertia factorial plane $[11,27]$. Permutation tests were conducted to assess the statistical significance of the co-variation between physical or chemical soil properties and termites or ants communities.

\subsubsection{General linear model}

The occurrence of each ant and termite species was then analyzed using a Generalized Linear Model (GLM) testing for the effect of the region, land use and physical and chemical variables on occurrences. The GLM is based on a flexible generalization of ordinary linear models that allows for response variables to follow other distributions than the normal distribution [28, 29]. Poisson

distributions were used on species present in 5 or more samples to avoid the issue of zero-inflated Poisson regression. GLM were run on 20 ant species and 6 termite species. An automatic stepwise selection procedure was implemented starting with a model without any effect to determine the variables to be kept in the model. All analyses were conducted in the R environment and for the multivariate analyses was used the ade4 library [30, 31].

\section{Results}

\subsection{Soil engineers diversity}

A total of 5154 ant individuals representing 33 genera, 9 subfamilies and 91 ant species were found, 64 of those were identified to the species level and the remaining 28 are identified as morphospecies because they belong to diverse genera with poorly known taxonomy or mega diverse groups (see complete list in Appendix 1). Termite comprised 8052 individuals belonging 
to 4 families, 5 subfamilies, 10 genera and 16 species were identified (see complete list in Appendix 2).

\subsection{Effect of region or land use on soil properties}

\subsubsection{Physical soil properties.}

Between-group analyses performed on soil physical properties with land use as the explanatory variable extracted $17.42 \%$ of the total variance (Fig. 1a). Axes 1 and 2 accounted for $76.82 \%$ and $16.69 \%$ of the variance extracted, respectively. Three physical variables contributed to the formation of axis 1, three on the negative side (mesoporosity, sand concentration and available water capacity) and on in the positive side (microporosity). Axis 1 discriminated soil physical aspects, along with soil water availability for plant. Annual crops and improved pastures are on the positive side and rubber plantations, oil palm plantations and savannas on the negative side. Three variables contributed to the formation of axis 2, one on the positive side (macroporosity) and two on the negative side (silt concentration and bulk density). Axis 2 discriminated soil physical structure, along a soil compaction gradient, with rubber plantations and annual crops on the positive side and improved pastures and savannas on the negative side. A Monte-Carlo permutation test showed that land use is significantly related to soil physical properties $(\mathrm{p}=$ $0.001)$.

Between-group analyses performed on physical soil properties taking region as the explanatory variable extracted $8.04 \%$ of the total variance (Fig. 1b). Axes 1 and 2 accounted for $78.48 \%$ and $21.24 \%$ of the variance extracted, respectively. Four physical variables contributed to the formation of axis 1 , three for the positive side (macro and mesoporosity and silt concentration) and one on the negative side (bulk density). The Carimagua region is on the positive side and Puerto López and Puerto Gaitán regions on the negative side. Three variables contributed to the 
formation of axis 2, one on the positive side (soil moisture) and two on the negative side (silt concentration and bulk density). The Puerto López region is on the positive side and Puerto Gaitán region on the negative side. A Monte-Carlo permutation test showed that region significantly determines soil physical aspects $(\mathrm{p}=0.01)$.

\subsubsection{Chemical soil properties.}

Between-group analyses performed on soil chemical properties taking land use as the explanatory variable extracted $27.87 \%$ of the total variance (Fig. 2a). Axes 1 and 2 accounted for $84.90 \%$ and $11.39 \%$ of the variance extracted, respectively. Two chemical variables contributed to the formation of axis 1, all on the positive side (Al total concentration and Al saturation). Annual crops are on the positive side and all other land uses on the negative side. Three variables contributed to the formation of axis 2 , all on the positive side $(\mathrm{C}$ and $\mathrm{N}$ concentration and $\mathrm{Cu}$ presence). Improved pastures are on the positive side while other land uses are on the negative side. A Monte-Carlo permutation test showed that land use is significantly related to chemical aspects of the soil $(\mathrm{p}=0.001)$.

Between-group analyses performed on chemical soil properties taking region as the explanatory variable extracted $5.42 \%$ of the total variance (Fig. 2b). Axes 1 and 2 accounted for $69.81 \%$ and $30.19 \%$ of the variance extracted, respectively. Three chemical variables contributed to the formation of axis 1, two for the positive side ( $\mathrm{pH}$ and available $\mathrm{P}$ ) and one on the negative side (N concentration). The Carimagua and Puerto Gaitán regions are on the positive side and Puerto López region is on the negative side. Three variables contributed to the axis 2 , one on the positive side (Fe concentration) and two on the negative side ( $\mathrm{Zn}$ and $\mathrm{K}$ concentrations). The Carimagua and Puerto Gaitán regions are on the positive side and Puerto López region is on the negative 
side. A Monte-Carlo permutation test showed that region has a significant impact on soil chemical properties $(\mathrm{p}=0.034)$.

\subsection{Effect of region or land use on community structure}

\subsubsection{Termites.}

Between-group analyses performed on the termite community data set with land use as the explanatory variable extracted $10.32 \%$ of the total variance (Fig. 3). Axes 1 and 2 accounted for $58.44 \%$ and $11.38 \%$ of the variance extracted, respectively. Six termite species contributed to the formation of axis 1, three on the positive side (Neocapritermes talpoides, Nasutitermes sp. 2 and Termes sp.1) and three on the negative side (Anoplotermes sp.1 and sp.4 and Neocapritermes talpa). Axis 1 discriminated termite communities according to land uses, with savannas on the positive side and all other land uses on the negative side. Three termite species contributed to the formation of axis 2, two on the positive side (Neocapritermes talpoides, Nasutitermes sp.2) and one on the negative side (Neocapritermes talpa). Axis 2 discriminated termite communities with annual crops and oil palm plantations on the positive side and savannas on the negative side. A Monte-Carlo permutation test showed that land use is significantly associated with termite communities $(\mathrm{p}=0.028)$. No effect of region on termite communities was observed.

\subsubsection{Ants.}

Between-group analyses performed on the ant community data set taking land use as the explanatory variable extracted $6.93 \%$ of the total variance (Fig. 4a). Axes 1 and 2 accounted for $34.88 \%$ and $29.76 \%$ of the variance extracted, respectively. Eight ant species contributed to the formation of axis 1, all on the positive side (Hypoponera punctatissima sp.1, Solenopsis sp.3, Ectatomma brunneum, Pachycondyla arhuaca, Pheidole sp.4, Brachymyrmex sp.2, Paratrechina longicornis and Hypoponera punctatissima sp.2). Axis 1 discriminated ant communities 
according to land uses, with annual crops and oil palm plantations on the positive side and improved pastures on the negative side. Twenty ant species contributed to the formation of axis 2 , ten on the positive side (Monomorium pharaonis, Cyphomyrmex rimosus, Acropyga palaga, Typhlomyrmex sp.1, Solenopsis sp.4, Pseudomyrmex gracilis sp.1, Pheidole sp.2 and sp.3, Acromyrmex sp.1, Acropyga sp.1) and ten on the negative side (Camponotus sp.2, Crematogaster negripliosa, Pachycondyla sp.1, Neivamyrmex punctaticeps, Odontomacus yucatecus, Labidus praedator, Solenopsis sp.1, Camponotus sp.3, Pseudomyrmex gracilis sp.2, Ectatomma tuberculatum). Axis 2 discriminated ant communities with improved pastures and savannas on the positive side and rubber plantations on the negative side. A Monte-Carlo permutation test showed that land use is significantly associated with the ant communities present $(\mathrm{p}=0.032)$. Between-group analyses performed on the ant community data set with region as the explanatory variable extracted $4.46 \%$ of the total variance (Fig. 4b). Axes 1 and 2 accounted for $56.41 \%$ and $43.59 \%$ of the variance extracted, respectively. Ten ant species contributed to the formation of axis 1 , all on the positive side (Typhlomyrmex sp.1, Pseudomyrmex gracilis sp.2, Odontomacus yucatecus, Hypoponera punctaticeps, E. tuberculatum, Acropyga palaga, Acropyga sp.1, Camponotus sp.1, Crematogaster nigropilosa, C. obscurata). Axis 1 discriminated ant communities according to region, with Carimagua on the positive side and Puerto Gaitán and Puerto López on the negative side. Seventeen ant species contributed to the formation of axis 2 , ten on the positive side (Pachycondyla arhuaca, Hypoponera sp.2, Pheidole sp.2 and sp.3, Pseudomyrmex gracilis sp.5, Solenopsis sp.4, Crematogaster curvispinosa, C. foliocrypta, Solenopsis sp.1 and Brachymyrmex sp.2) and seven on the negative side (Pheidole sp.4, B. longicornis, Dolichoderus bispinosus, C. rochai, Acanthostichus sanchezorum, Pseudomyrmex pallens and Solenopsis sp.2). Axis 2 discriminated ant communities with the Puerto López region 
on the positive side and Puerto Gaitán on the negative side. A Monte-Carlo permutation test showed that region significantly affects ant communities $(\mathrm{p}=0.001)$.

Co-inertia analysis, to analyze covariation with soil physical and chemical properties, was also used on ant or termite species occurrences. However, no significant co-variation was found between physical or chemical soil properties and termite or ant community data sets.

\subsection{Effect of environmental factors on soil engineer species occurrence}

General linear models (GLM) testing the effect of environmental factors (region, land use, physical and chemical soil properties) on soil engineer species occurrence allowed for examination of the association between soil properties, regional differences and land use and each ant (Table 2) and termite (Table 3) species taken separately. This work only considered the species present in five or more sampled fields. Nineteen soil physical and chemical properties, in addition to land use and region, are significantly associated with the occurrences of 15 ant species (Table 2). Two species of ants were influenced by the region (Crematogaster rochai and Pheidole subarmata) and 5 by land use Acromyrmex sp.1, C. nigropilosa, Ectatomma brunneum, Nylanderia fulva, Ph. subarmata). The species significantly affected by the highest number of factors, Solenopsis geminata was positively related to $\mathrm{CEC}$ and $\mathrm{Cu}$ concentration and negatively associated with Mn concentration, mesoporosity and silt. Five species were significantly associated with four different combinations of environmental variables: $C$. rochai $(\mathrm{pH}, \mathrm{Ca}$ and B concentrations and region), E. brunneum (cation exchange capacity, Fe concentration, total porosity and land use), N. fulva (B concentration, macroporosity, silt concentration and land use) and finally, Ph. subarmata (CEC, B concentration, land use and region); (see Table 2). Interestingly, $\mathrm{CEC}$ is the factor that was associated with the highest number of ant species, two positively and three negatively. This was followed by B concentration which was associated with 
four ant species, two positively and two negatively. In addition, land use was related to five ant species: Acromyrmex sp.1 (higher occurrence in improved pastures than in oil palm plantations), C. nigropilosa (higher occurrence in annual crops than in savannas), E. brunneum (higher occurrence in rubber than in oil palm plantations), $N$. fulva (higher occurrence in annual crops than in improved pastures) and Ph. subarmata (higher occurrence in in annual crops than in oil palm plantations) (Table2).

Eleven soil physical and chemical variables, in addition to land use and region, are significantly associated with six termite species (Table 3), five of those variables have a positive association and eight a negative association. The observed occurrences of two termite species were significantly influenced by silt concentration: Grigiotermes sp.1 negatively and Syntermes modestus positively. Grigiotermes sp.1 and Grigiotermes sp. 2 were significantly associated with land use (high occurrence in annual crops than in improved pasture). Anoplotermes sp.4 was affected by the region (highest occurrence in Puerto López and lowest in Carimagua). Additionally, this species was associated with the three soil characteristics: negatively by $\mathrm{pH}$ and $\mathrm{Cu}$ concentration, and positively by volumetric moisture.

\section{Discussion}

Two groups of land use can be distinguished according to their ant communities: (1) savannas and (2) oil palm plantations, annual crops, rubber plantations and improved pastures (Fig. 4). Similarly, three groups of land use can be distinguished according to their termite communities: (1) rubber plantations, (2) improved pastures and savannas and (3) annual crops and oil palm plantations (Fig. 3). Co-inertia analyses suggest that there is no general relation between ants or termites and soil properties. However, this does not preclude the observance of significant relations between certain soil properties and species when the data are analyzed at the species 
level. Indeed, co-inertia tests for general patterns between groups of soil properties and groups of species and the fact that such patterns are not encountered does not exclude the possibility of significant relationships between single soil properties and species. Indeed, the GLM analyses show positive and negative relationships of soil properties with ant and termite species occurrence. Ants are positively associated with high soil porosity and negatively related with CEC (Table 2). Termites appear to be positively affected by physical factors such as the volumetric moisture, bulk density and macroporosity. Termites are also negatively associated with high soil chemical fertility (associated to high $\mathrm{pH}$ and high $\mathrm{N}, \mathrm{C}, \mathrm{Mn}$ and $\mathrm{Cu}$ concentrations, Table 3).

\subsection{Effect of the regions or land uses on soil properties}

This study was carried out along transect through the 'eastern Colombian plains'. In this region, there exists a gradient in precipitation between Puerto López and Carimagua as well as a subtle gradient in soil texture, with a higher sand concentration, in Puerto López than in Carimagua, and also a marked local variability [19]. This may cause slight differences in the physical and chemical properties of their soils. However, differences in soil chemical and physical properties between land uses appear to exert a much stronger influence on soils than regional trends.

Human activities such as the conversion of natural land into cropland can significantly affect and modify soil chemical and physical properties, often resulting in land degradation [30]. Due to the high bulk densities encountered in this region, establishment of annual crops requires improving soil physical properties via tillage [31], which serves to increase soil porosity. It was indeed found that the microporosity increases in annual crops, but mesoporosity decreases. In improved pastures, compaction by cattle might be expected to increase bulk density and to decrease pore space [32]. However, we found relatively low bulk densities in improved pastures [19], and this 
might be explained by high earthworm densities and/or root growth in this land use [7]. In fact, the high microporosity under annual crops and improved pastures might be linked to their lower sand concentration and slightly higher silt concentration. Such concentrations are difficult to explain, but it can be argued that farmers may select finer textured and probably more fertile soils for annual crops and improved pastures. Savannas and oil palm plantations have high bulk density and clay concentration, this was unexpected for the oil palm plantations and may be related to farmers choosing heavier textured soils for these plantations. Rubber plantations have a high macro and mesoporosity, which could be explained by the high amounts of biogenic soil aggregates in these plantations or the high density of perennial roots. Alternatively, farmers may choose savanna soils that exhibit among other features a higher porosity, a deeper profile and high available water storage capacity to implement these plantations [19]. Annual crops are characterized by a high chemical fertility, with elevated values of base cations. This is probably due to the creation of an arable layer when savannas are converted into cropland [31], which involves substantial inputs of lime, fertilizers and deep tillage [19, 31]. In contrast, rubber, oil palm plantations and savannas have relatively low chemical fertility, reflecting both the low intrinsic nutrient status of the parent soil in the Altillanura [19] and reduced fertilization.

\subsection{Effect of the regions or land uses and ant or termite communities.}

In the Colombian Altillanura, termites represent over $45 \%$ of the total biomass of macroinvertebrates [33]. In general, termites are prolific and are very important for the ecology of savannas. Termites recycle mineral nutrients through their feeding activities, they modify soil texture and create heterogeneity in soil properties through the building of termite mounds. This study confirms that termite communities in savannas differ from the other land uses (Fig. 3), mainly due to the presence of two species: Nasutitermes sp.2 and N. talpoides. Their ecology is 
poorly known, but they are subterranean and this type of nesting behavior is likely more susceptible to tillage or intensive grazing. In this sense, savanna is the only system where tillage has not been carried out, highlighting that this practice may be quite important in determining termite assemblage in this region. In the other land uses, the dominance of a particular group of termites is not evident, but the genus Heterotermes was present in almost all of them, suggesting a greater plasticity. Annual crops were negatively associated with all termite species. Indeed, this system does not provide the ideal conditions for the establishment of termite colonies due to tillage or the application of pesticides $[34,35]$ and the absence of permanent vegetation cover. This result is contrary to Barros et al. [9] who found the highest termite densities in annual crops within the Brazilian Amazonia. However, the authors mention that they collected macrofauna immediately after harvest, when there are crop residues on the soil, which could favor some termite groups. In our case, the sampling of soil fauna was carried out during the middle of the cropping season.

Ant communities are strongly influenced by habitat type [34] vegetation structure and land management [16] especially in South American savannas [35]. This is because vegetation is a major regulator of microclimatic conditions, which influences ant activity. In the present case, this is clearly supported by the difference between savanna and improved pastures on the one side, and rubber plantations and oil palm plantations on the other. Past research suggests that ecosystems with trees are more complex and offer a higher diversity of micro-habitats and niches, which could allow them to host a higher ant diversity [36]. However, in this study improved pastures showed the highest numbers of species followed by savannas, and they share 31 species in total [16]. This finding contrasts with Dëcaens et al. [7], who found lower abundances of ants in pastures of the same region. This result is likely due to the fact that their pastures were 
overgrazed, which reduces herbaceous cover. In this study, the similarity between ant communities in savanna and improved pastures can be explained by: (1) the majority of savanna soils have been impoverished by decades of extensive grazing and dry season fires $[19,37]$ which could reduce soil biodiversity; (2) soil invertebrate communities tend to be better preserved during a land use change when the new system has a vegetative cover similar to the original [38] and savannas and improved pastures are the most similar land uses studied because they are both dominated by a permanent herbaceous layer. We expected ant communities to be similar in both oil palm plantations and rubber plantations, as they are both comprised of trees. However, ant communities are more similar between annual crops and oil palm plantation (they share about the $70 \%$ of their species). We suppose that this may partially be attributed to the presence of predatory ants, such as Hypoponera punctatissima sp.1 and Ectatomma brunneum, in both land uses. In these land uses they are likely to encounter abundant prey, such as immature Lepidotera or mites, which are very common in annual crops and young oil palm plantations. Moreover, predatory ants have been shown in some cases to greatly influence the structure of ant communities [39].

\subsection{Effect of soil properties, regions and land uses on ant or termite species}

Overall, termite and ant communities are not linked to soil properties, as was indicated by coinertia analyses. However, general lineal models applied separately to each species document many cases of significant positive or negative associations of soil characteristics on ant and termite species. Co-inertia is a multivariate method to assess the similarity between the overall structures of two data sets [38]. The GLM generalizes linear regression by allowing for the association of response variables, here the occurrence of termite and ant species to explanatory variables [11]. Thus, the apparent contradiction between the results of co-inertia and GLM 
analyses would be due to the fact that environmental variables and land uses do not affect ant and termite communities in a consistent way across all species or due to these species could have a mosaic distribution along the terrain, which cannot be evaluated by the employed method.

Acromyrmex sp.1 and Solenopsis geminata, (that construct their nest with, on and within soil) were positively associated with high values of CEC, which is related to clay concentation, organic matter and overall soil fertility. Such characteristics correspond well to improved pastures, the land use where these species were frequently encountered. Alternatively, the observed association between these species and CEC, could be due to the impact of ants (or termites) on soil properties, and not only to their habitat preference. We also found that total $\mathrm{N}$ to be positively associated with Crematogaster longispina. This could be explained by the fact that ants tend to increase $\mathrm{C}$ and mineral nutrient concentration in soils especially in and around their nests [7]. The same authors mention that soil bulk density tends to decrease with the presence of ants due to their burrowing activities. This is in line with the fact that nine ant species are associated with bulk density, and that seven of them are negatively linked to bulk density.

E. brunneum, is encountered less often in rubber plantations and improved pastures, but more often in oil palm plantations and annual crops. Gomes et al. [38] described this species as a solitary predatory with well-developed stingers. They build their nest on the ground and their abundance is remarkable in open fields or degraded areas, such as grasslands, plantations and roads, among others. It can be hypothesized that this predatory species is more common in oil palm plantations and annuals crops that are more suitable for its foraging and may host suitable prey [17].

In Colombia, Nylanderia fulva is an introduced species and is considered a serious pest that often displaces native fauna [39]. This species was mainly associated with annual crops. This land use 
leads the highest level of disturbance (tillage and pesticides), which might allow N.fulva to displace native termites. Soils of annual crops tend to have a high chemical fertility, and this may explain why termites tend to be associated with low chemical fertility in this study. This finding is consistent with Barros et al. [9] who suggested that termite diversity decreases with land use intensification because of the negative impact of tillage, pesticides and the absence of perennial vegetation. Some termite species are associated with soil physical characteristics [3]. For example, Heterotermes tenius is positively associated with mesoporosity and available water capacity. This is a subterranean termite that is considered as an agricultural pest because they feed on wood or other cellulosic materials [26]. It can be hypothesize that this species prefers more porous soil for nesting, and we have shown that soil porosity is higher in rubber plantations. This is consistent with the fact that $H$. tenius likely finds ideal conditions for feeding and nesting in rubber plantations [26]. Many species (e.g. Syntermes modestus and Neocapritermes talpa) are associated to low microporosity, silt and clay values. This contradicts Barros et al. [9], who say that high soil clay concentrations are favorable to termites because clay is important for all of the structures they build. This also contradicts Bruyn and Conacher [30] who consider that termites increase water infiltration and aeration by incorporating organic matter into the soil and constructing galleries within the soil. Also, one of the major effects of termites in ecosystems is their role in loosening of soils (i.e., reduction of bulk density) [12]. In this sense, if the termite need for clay and their impact on porosity can be generalized, the association of termites with low clay and microporosity values requires a supplementary mechanism. We can hypothesize that this association would thus be due to the effect of land use on termite communities and not to the direct effect of the associated soil properties on termites. 


\section{Conclusion}

Here, land use and soil characteristics explain only a small part of the overall variability in ant and termite communities. The remaining unexplained variability could be attributed to the influence of factors that have not been taken into account: (1) interactions with other organisms such as predators and prey and (2) the history of each cultivated plot, (3) the precise structure of the landscape. However, this study showed that ant and termite communities depend on land use (type of vegetation cover), which is linked to management practices (inputs of fertilizer, tillage, etc). Annual crops are the most detrimental land use for ants and termites and tillage is probably the most important negative management driver associated with this effect $[40,41]$. Because ants and termites are important soil organisms that contribute to the maintenance of soil structure [3], maintaining a high diversity of these soil engineers could increase the long-term provisioning of the ecosystem services they help regulate. Grimaldi et al. 2014 [42], showed that landscape structure drives soil ecosystem services of regulation and support in Amazonian landscape. Some of them depend partially on soil ecosystem engineers [4], which suggests that these services and soil biodiversity should be managed at the scale of the land use mosaic. In order to maintain the benefits that soil ecosystem engineers provide, two types of recommendations may be suggested: 1) adapt practices within the more intensively managed land uses, especially annual crops, to be less detrimental. In this sense practices such as tillage and pesticide use could be reduced; and 2) decrease the proportion of annual crops in the landscape and keep and/or restore semi-natural systems such as savannas and improved pastures, which should facilitate the maintenance of heterogeneous mosaics of land uses that are favorable to soil organisms [19]. 


\section{Acknowledgements}

This research was funded in part by the Colombian Ministry of Agriculture. CS was funded by a doctoral scholarship from Departamento Administrativo de Ciencia, Tecnología e Innovación COLCIENCIAS in Colombia.We are grateful to the farmers who allowed us to conduct research on their land. We also thank the Soils-LAC team of CIAT including Maria del Pilar Hurtado, Paula Chaparro, Sandra Loaiza, Cesar Botero, Carolina Quintero, Arvey Alvarez, and Edgar Rodriguez who helped with field and laboratory works. We greatly appreciate support from a number of researchers and technicians at CORPOICA - La Libertad who provided information and logistical support in field aspects of the research. We are very thankful to the anonymous reviewers for their useful comments which have helped us to increase the quality of the manuscript.

\section{References}

[1] D.M. Olson, E. Dinerstein, E.D. Wikramanayake, N.D. Burgess, G.V.N. Powell, E.C. Underwood, J.A. D'Amico, I. Itoua, H.E. Strand, J.C. Morrison, C.J. Loucks, T.F. Allnutt, T.H. Ricketts, Y. Kura, J.F. Lamoreux, W.W. Wettengel, P. Hedao, K.R. Kassem, Terrestrial Ecoregions of the World: A New Map of Life on Earth, Bioscience. 51 (2001) 933-938.

[2] M.H. Romero-Ruiz, S.G.A. Flantua, K. Tansey, J.C. Berrio, Landscape transformations in savannas of northern South America: Land use/cover changes since 1987 in the Llanos Orientales of Colombia, Appl. Geogr. 32 (2012) 766-776.

[3] P. Lavelle, A. V. Spain, Soil ecology, Kluger Academic Publishers, Netherlands, 2001.

[4] P. Lavelle, T. Decaëns, M. Aubert, S. Barot, M. Blouin, F. Bureau,P. Margerie, P. Mora, J.P Rossi, Soil invertebrates and ecosystem services, Eur. J. Soil Biol. 42 (2006) S3-S15.

[5] P. Lavelle, D. Bignell, M. Lepage, W. Wolters, P. Roger, P. Ineson, O.W. Heal, S. Dhillon, Soil function in a changing world : the role of invertebrate ecosystem engineers, Eur. J. Soil Biol. 33 (1997) 159-193.

[6] C. G. Jones, J. H. Lawton, M. Shachak, Organisms as ecosystem engineers. Oikos. 69 (1994) 373-386.

[7] T. Decaëns, P. Lavelle, J.J. Jimenez, G. Escobar, G. Rippstein, Impact of land management on soil macrofauna in the Oriental Llanos of Colombia, Eur. J. Soil Biol. 30 (1994) 157-168. 
[8] M.M. Rocha, E.M. Cancello, T.F. Carrijo, Neotropical termites: Revision of Armitermes Wasmann (Isoptera, Termitidae, Syntermitinae) and phylogeny of the Syntermitinae, Syst. Entomol. 37 (2012) 793-827.

[9] E. Barros, A. Neves, E. Blanchart, E.C.M. Fernandes, E. Wandelli, P. Lavelle, Development of the soil macrofauna community under silvopastoral and agrosilvicultural systems in Amazonia, Pedobiologia. 47 (2003) 273-280.

[10] T. Decaëns, J.J. Jiménez, E. Barros, A. Chauvel, E. Blanchart, C. Fragoso, P. Lavelle, Soil macrofaunal communities in permanent pastures derived from tropical forest or savanna, Agric. Ecosyst. Environ. 103 (2004) 301-312.

[11]M. Crawley, The R Book, 2nd edition, London U.K., 2012.

[12] P. Jouquet, S. Traoré, C. Choosai, C. Hartmann, D. Bignell, Influence of termites on ecosystem functioning. Ecosystem services provided by termites, Eur. J. Soil Biol. 47 (2011) $215-222$.

[13] S.H. Luke, T.M. Fayle, P. Eggleton, E.C. Turner, R.G. Davies, Functional structure of ant and termite assemblages in old growth forest, logged forest and oil palm plantation in Malaysian Borneo, Biodivers. Conserv. 23 (2014) 2817-2832.

[14] R. Marichal, M. Grimaldi, A. Feijoo M., J. Oszwald, C. Praxedes, D.H. Ruiz Cobo, M.P. Hurtado, T. Desjardins, M. Lopes da Silva, L. G. da Silva Costa, I. Souza Miranda, M. N. Delgado Oliveira, G. G. Brown, S. Tsélouiko, M. Bonifacio Martins, T. Decaëns, E. Velásquez, P. Lavelle, Soil macroinvertebrate communities and ecosystem services in deforested landscapes of Amazonia, Appl. Soil Ecol. 83 (2014) 177-185.

[15] C. Heiniger, S. Barot, J.-F. Ponge, S. Salmon, L. Botton-Divet, D. Carmignac, F. Dubs, Effect of habitat spatiotemporal structure on collembolan diversity, Pedobiologia. 57 (2014) 103117.

[16] C. Sanabria, P. Lavelle, S.J. Fonte, Ants as indicators of soil-based ecosystem services in agroecosystems of the Colombian Llanos, Appl. Soil Ecol. 84 (2014) 24-30.

[17] B. Hölldobler, E.O. Wilson, The Ants, Springer-Verlag, Berlin/Heidelberg, 1990.

[18] F. Fernández, Introducción a las hormigas de la región Neotropical, Instituto de Investigación de Recursos Biológicos Alexander von Humboldt, Bogotá, Colombia, 2003.

[19] P. Lavelle, N. Rodríguez, O. Arguello, J. Bernal, C. Botero, P. Chaparro, Y. Gómez, A. Gutiérrez, M.P. Hurtado, S. Loaiza, S. X. Pulido, E. Rodríguez, C. Sanabria, E. Velásquez, S. J. Fonte, Soil ecosystem services and land use in the rapidly changing Orinoco River Basin of Colombia, Agric. Ecosyst. Environ. 185 (2014) 106-117.

[20] AntWeb, (2014). www.antweb.org (accessed January 20, 2014).

[21] J.T. Longino, Ants of Costa Rica, (2004). www.evergreen.edu/ants/AntsofCostaRica (accessed January 20, 2015). 
[22] K.R. Laossi, S. Barot, D. Carvalho, T. Desjardins, P. Lavelle, M. Martins, D. Mitja, A. C. Rendeiro, G. Rousseau, M. Sarrazin, E. Velásquez, M. Grimaldi, Effects of plant diversity on plant biomass production and soil macrofauna in Amazonian pastures, Pedobiologia. 51 (2008) 397-407.

[23] J.M. Anderson, J.S.I. Ingram, Tropical Soil Biology and Fertility. A Handbook of Methods, Second Ed, CAB International, Wallingford U.K., Wallingford U.K., 1993.

[24] E.E. Palacio, F. Fernández, Clave para las subfamilias y géneros, in: F. Fernández (Ed.), Introducción a Las Hormigas La Región Neotropical, 1st edition., Instituto de Investigación de Recursos Biológicos Alexander von Humboldt., Bogotá D.C., 2003: pp. 233-260.

[25] B. Bolton, Identification Guide to the Ant Genera of the World, Harvard University Press, Cambridge, 1994.

[26] R. Constantino, The pest termites of South America : taxonomy, distribution and status, J. Appl. Ent. 126 (2002) 355-365.

[27] F. Baty, M. Facompré, J. Wiegand, J. Schwager, M.H. Brutsche, Analysis with respect to instrumental variables for the exploration of microarray data structures., BMC Bioinformatics. 7: 422 (2006) 1-8.

[28] J. Thioulouse, Y. Prin, R. Duponnois, Multivariate analyses in soil microbial ecology: a new paradigm, Environ. Ecol. Stat. 19 (2012) 499-520.

[29] R Foundation for Statistical Computing, R Development Core Team. R: A Language and Environment for Statistical Computing, Vienna, Austria. 2010.

[30] L.A. Lobry de Bruyn, A. J. Conacher. The role of termite and ants in soil modification: A review, Aust. J. Soil. Res. 28 (1990) 55-93

[31] E. Amézquita, R.J. Thomas, I.M. Rao, D.L. Molina, P. Hoyos, Use of deep-rooted tropical pastures to build-up an arable layer through improved soil properties of an Oxisol in the Eastern Plains (Llanos Orientales) of Colombia, Agric. Ecosyst. Environ. 103 (2004) 269-277.

[32] T. Decaëns, P. Lavelle, J.J. Jiménez, G. Escobar, G. Rippstein, J. Schneidmadl, J. I. Sanz, P. Hoyos, R. J. Thomas, Impact of land management on soil macrofauna in the Eastern plains of Colombia, in: J.J. Jiménez, R.J., Thomas (Eds.), Soil Macroinvertebrate Communities Neotropical Savannas of Colombia, CIAT publication 324, 2001, Pp 19-41.

[33] H.I.J. Black, M.J.N. Okwakol, Agricultural intensification, soil biodiversity and agroecosystem function in the tropics: the role of termites, Appl. Soil Ecol. 6 (1997) 37-53.

[34] C.B. Costa-Milanez, G. Lourenço-Silva, P.T.A. Castro, J.D. Majer, S.P. Ribeiro, Are ant assemblages of Brazilian veredas characterized by location or habitat type?, Brazilian J. Biol. 74 (2014) 89-99. 
[35] H.L. Vasconcelos, M.F. Leite, J.M.S. Vilhena, A.P. Lima, W.E. Magnusson, Ant diversity in an Amazonian savanna: Relationship with vegetation structure, disturbance by fire, and dominant ants, Austral Ecol. 33 (2008) 221-231.

36] J. Cabra-Garcia, C. Bermudez-Rivas, A.M. Osorio, P. Chacon, Cross-taxon congruence of a and $\mathrm{b}$ diversity among five leaf litter arthropod groups in Colombia, Biodivers. Conserv. 21 (2012) 1493-1508.

[37] S. Dray, D. Chessel, J. Thioulouse, Co-inertia analysis and the linking of data tables, Ecology. 84 (2003) 3078-3089.

[38] L. Gomes, I.C. Desuó, G. Gomes, Behavior of Ectatomma brunneum (Formicidae: Ectatomminae) Preying on Dipterans in Field Conditions, Sociobiology. 53 (2009) 913-926.

[39] A.M. Arcila, L.A. Gómez, P. Ulloa-Chacón, lmmature Development and Colony Growth of Crazy ant Paratrechina fulva Under Laboratory Conditions (Hymenoptera: Formicidae), Sociobiology. 39 (2002) 307-321.

[40] F.A. Schmidt, C.R. Ribas, J.H. Schoereder, How predictable is the response of ant assemblages to natural forest recovery? Implications for their use as bioindicators, Ecol. Indic. 24 (2013) 158-166.

[41] R.K. Sharma, K. Srinivasa Babu, R.S. Chhokar, A. K. Sharma, Effect of tillage on termites, weed incidence and productivity of spring wheat in rice-wheat system of North Western Indian plains, Crop Prot. 23 (2004) 1049-1054.

[42] M. Grimaldi, J. Oszwald, S. Dolédec, M.P. Hurtado, I. de Souza Miranda, X. A. de Sartre, W. Santos De Assis, E. Castaneda, T. Desjardins, F. Dubs, E. Guevara, V. Gond, T.T. Santana Lima, R. Marichal, F. Michelotti, D. Mitja, N. Cornejo Noronha, M.N Delgado Oliveira, B. Ramirez, G. Rodriguez, M. Sarrazin, Jr. M. Lopes Da Silva L. Gonzaga Silva Costa, S. Lindoso de Souza, I. Veiga, E. Velasquez, P. Lavelle, Ecosystem services of regulation and support in Amazonian pioneer fronts: Searching for landscape drivers, Landsc. Ecol. 29 (2014) 311-328. 


\section{Tables.}

2

3 Table 1. List of chemical and physical variables used in the study, with their description and 4 unit.

\begin{tabular}{|c|c|c|c|}
\hline Chemical Variables & Description & Unit & Technique \\
\hline $\mathrm{pH}$ & Hydrogen potential & -- & Potentiometric \\
\hline $\mathrm{N}$ & Nitrogen Total & $\mathrm{g} \mathrm{kg}^{-1}$ & UV-VIS \\
\hline $\mathrm{C}$ & Carbon Total & $\mathrm{g} \mathrm{kg}^{-1}$ & UV-VIS \\
\hline $\mathrm{P}$ & Available Phosphorus Total & $\mathrm{mg} \mathrm{kg}^{-1}$ & UV-VIS \\
\hline K & Potassium Total & $\mathrm{mg} \mathrm{kg}^{-1}$ & Atomic absorption spectroscopy \\
\hline $\mathrm{Ca}$ & Calcium Total & $\mathrm{mg} \mathrm{kg}^{-1}$ & Atomic absorption spectroscopy \\
\hline $\mathrm{Mg}$ & Magnesium Total & $\mathrm{mg} \mathrm{kg}^{-1}$ & Atomic absorption spectroscopy \\
\hline $\mathrm{Al}$ & Aluminum Total & $\mathrm{mg} \mathrm{kg}^{-1}$ & Atomic absorption spectroscopy \\
\hline CEC & Cation Exchange Capacity & $\mathrm{cmol} \mathrm{kg}^{-1}$ & Potentiometric \\
\hline SAl & Aluminum Saturation & $\%$ & Potentiometric \\
\hline $\mathrm{S}$ & Sulfur Total & $\mathrm{mg} \mathrm{kg}^{-1}$ & UV-VIS \\
\hline B & Boron Total & $\mathrm{mg} \mathrm{kg}^{-1}$ & UV-VIS \\
\hline $\mathrm{Fe}$ & Iron Total & $\mathrm{mg} \mathrm{kg}^{-1}$ & UV-VIS \\
\hline $\mathrm{Mn}$ & Manganese Total & $\mathrm{mg} \mathrm{kg}^{-1}$ & Atomic absorption spectroscopy \\
\hline $\mathrm{Cu}$ & Copper Total & $\mathrm{mg} \mathrm{kg}^{-1}$ & Atomic absorption spectroscopy \\
\hline $\mathrm{Zn}$ & Zinc Total & $\mathrm{mg} \mathrm{kg}^{-1}$ & Atomic absorption spectroscopy \\
\hline Physical Variables & Description & Unit & Technique \\
\hline SM & Soil Moisture & g $100 \mathrm{~g}^{-1}$ & \\
\hline VM & Volumetric Moisture & $\mathrm{cm} 100 \mathrm{~cm}^{-1}$ & \\
\hline $\mathrm{BD}$ & Bulk density & $\mathrm{g} \mathrm{cm}^{-3}$ & Rings and clod \\
\hline AWC & Available Water Capacity & $\%$ & \\
\hline MAC & Macropores $(>3 \mu \mathrm{m})$ & $\%$ & Yolder \\
\hline MES & Mesopores $(0.03-3 \mu \mathrm{m})$ & $\%$ & Yolder \\
\hline MIC & Micropores $(<0.03 \mu \mathrm{m})$ & $\%$ & Yolder \\
\hline $\mathrm{Sa}$ & Sand & $\%$ & Bouyoucos \\
\hline $\mathrm{Si}$ & Silt & $\%$ & Bouyoucos \\
\hline $\mathrm{Cl}$ & Clay & $\%$ & Bouyoucos \\
\hline
\end{tabular}

5 
1 Table 2. Effect of environmental descriptors (physical and chemical soil properties (for 2 codes, see Table1), land uses (IP. Improved Pasture, S. Savanna, OP: Oil Palm plantation, 3 AC. Annual Crop, R: Rubber plantation) and regions (PL: Puerto López, PG: Puerto Gaitán, 4 CAR: Carimagua) on the occurrence of ant species. The results come from an automatic step5 wise procedure. Only variables with a significant effect and species present in 5 or more 6 samples were kept. \% sp with significant effect: Total number of species with effect of 7 physical and chemical features; $\%$ sp with positive effect: Percentage of species with positive 8 effect. \% sp with negative effect: Percentage of number of species with negative effect; P-

9 value: $* * *=0.001, * *=0.01, *=0.05,^{\circ}=0.10$. 


\begin{tabular}{|c|c|c|c|c|c|c|c|c|c|c|c|c|c|c|c|c|c|c|c|c|c|c|}
\hline & pH & $\mathbf{N}$ & C & $\mathbf{C a}$ & Mg & CEC & $\mathbf{S}$ & B & $\mathbf{F}$ & Mn & $\mathbf{C u}$ & VM & BD & MAC & MES & MIC & POR & $\mathbf{S i}$ & $\mathbf{C l}$ & Land Use & Region & Occurrence \\
\hline Acromyrmex sp. 1 & & & ${ }^{\circ}(-)$ & & & $*(+)$ & & & & & & & & & & & & & & $\begin{array}{l}* *(\mathrm{OP}<\mathrm{R}< \\
\mathrm{AC}<\mathrm{S}<\mathrm{IP})\end{array}$ & & 8 \\
\hline Brachycmyrmex sp. 1 & & & & & & & & & & $*(-)$ & & & & & $* *(-)$ & & & & & & & 37 \\
\hline Camponotus sp. 3 & & & & & & $*(-)$ & & & $*(-)$ & & & & & & & & & & & & & 5 \\
\hline Crematogaster longispina & & ${ }^{\circ}(+)$ & & & & & & & & & & & & ${ }^{\circ}(+)$ & & & & & & & & 5 \\
\hline Crematogaster nigropilosa & & & & ${ }^{\circ}(+)$ & & & & & & & & ${ }^{\circ}(-)$ & & & & & & & & $\begin{array}{l}*(\mathrm{AC}<\mathrm{OP}< \\
\mathrm{IP}<\mathrm{R}<\mathrm{S})\end{array}$ & & 12 \\
\hline Crematogaster rochai & ${ }^{\circ}(+)$ & & & $* * *(-)$ & & & & $* *(+)$ & & & & & & & & & & & & & $\begin{array}{l}*(\mathrm{PL}< \\
\mathrm{C}<\mathrm{PG})\end{array}$ & 7 \\
\hline Ectatomma brunneum & & & & & & ${ }^{\circ}(-)$ & & ${ }^{\circ}(+)$ & & & & & & & & & ${ }^{\circ}(+)$ & & & $\begin{array}{c}{ }^{\circ}(\mathrm{R}<\mathrm{IP}<\mathrm{AC} \\
<\mathrm{S}<\mathrm{OP})\end{array}$ & & 7 \\
\hline Ectatomma ruidum & $*(+)$ & & & & ${ }^{\circ}(-)$ & & & & & & & & $* *(+)$ & & & & & & & & & 14 \\
\hline Hypoponera creola & & & & & & & & & & & & & & & & & & & ${ }^{\circ}(+)$ & & & 18 \\
\hline Hypoponera opacior & & & ${ }^{\circ}(-)$ & & & & $* *(-)$ & & & & & & & & & $* * *(-)$ & & & $* *(+)$ & & & 16 \\
\hline Nylanderia fulva & & & & & & & & $*(-)$ & & & & & & ${ }^{\circ}(+)$ & & & & ${ }^{\circ}(+)$ & & $\begin{array}{l}* *(\mathrm{AC}<\mathrm{R}< \\
\mathrm{OP}<\mathrm{S}<\mathrm{IP})\end{array}$ & & 19 \\
\hline Pheidole inversa & & & & & & & & & $* *(+)$ & & & ${ }^{\circ}(+)$ & & & & & & & & & & 9 \\
\hline Pheidole sp. 1 & & & & & & & & & & $*(-)$ & $*(+)$ & & & & & & & & & & & 10 \\
\hline Pheidol subarmata & & & & & & $*(-)$ & & $* *(+)$ & & & & & & & & & & & & $\begin{array}{l}* *(\mathrm{AC}<\mathrm{R}< \\
\mathrm{S}<\mathrm{IP}<\mathrm{OP})\end{array}$ & $\begin{array}{c}* * *(\mathrm{PL}<\mathrm{C} \\
\quad<\mathrm{PG})\end{array}$ & 20 \\
\hline Solenopsis geminata & & & & & & ${ }^{\circ}(+)$ & & & & $*(-)$ & ${ }^{\circ}(+)$ & & & & $*(-)$ & & & $*(-)$ & & & & 7 \\
\hline $\begin{array}{c}\% \text { sp with } \\
\text { significant effect }\end{array}$ & 13.3 & 6.6 & 13.3 & 13.3 & 6.6 & 33.3 & 6.6 & 26.6 & 13.3 & 20 & 13.3 & 13.3 & 6.6 & 13.3 & 13.3 & 6.6 & 6.6 & 13.3 & 13.3 & 33.3 & 13.3 & 0 \\
\hline$\%$ sp with positive effect & 13 & 6.6 & 0 & 6.65 & 0 & 20 & 0 & 20 & 6.65 & 0 & 13.3 & 6.65 & 6.6 & 13.3 & 0 & 0 & 6.6 & 6.65 & 13.3 & -- & -- & -- \\
\hline$\%$ sp with negative effect & 0 & 0 & 13.3 & 6.65 & 6.6 & 13.3 & 6.6 & 6.6 & 6.65 & 20 & 0 & 6.65 & 0 & 0 & 13.3 & 6.6 & 0 & 6.65 & 0 & -- & -- & -- \\
\hline
\end{tabular}


Table 3. Effect of environmental descriptors (physical and chemical soil properties (for codes, see Table1), land uses (IP. Improved Pasture, S. Savanna, OP: Oil Palm plantation, AC. Annual Crops, R: Rubber plantations) and regions (PL: Puerto López, PG: Puerto Gaitán, CAR: Carimagua) on the occurrence of termite species. The results come from an automatic step-wise procedure. Only variables with a significant effect and species present in 5 or more samples were kept. \% sp with significant effect: Total number al of species with effect of physical and chemical features; \%sp with positive effect: Percentage of species with positive effect $\%$ sp with negative effect: Percentage of number of species with negative effect. Pvalue: $* * *=0.001, * *=0.01, *=0.05,{ }^{\circ}=0.10$

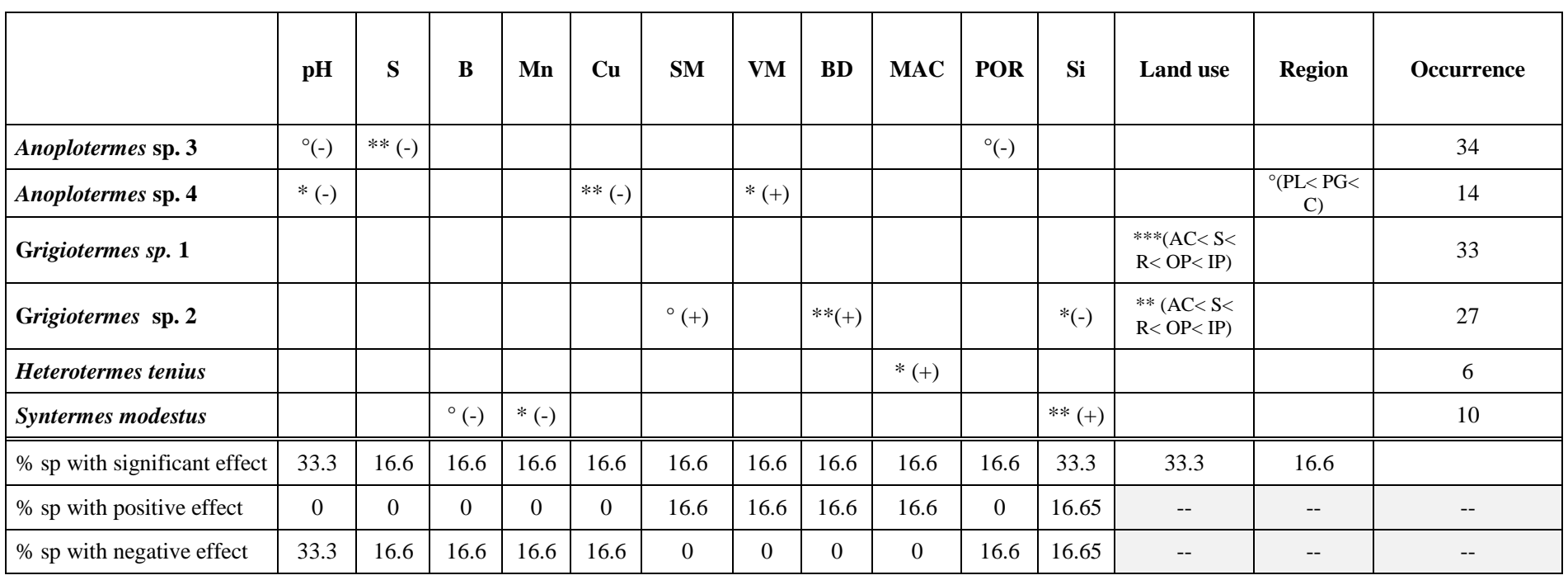


Appendix 1: List of ant species used in the analysis. Only species that appeared in 2 or more samples were kept. The last column (\#samples) gives the number of samples in which each ant specie appeared from a total of 75 samples.

\begin{tabular}{|c|c|c|}
\hline Species code & Species & \# samples \\
\hline Asa & Acanthostichus sanchezorum & 3 \\
\hline Am1 & Acromyrmex sp.1 & 8 \\
\hline App & Acropyga palaga & 3 \\
\hline Ap1 & Acropyga sp. 1 & 3 \\
\hline Blo & Brachymyrmex longicornis & 2 \\
\hline Br1 & Brachymyrmex sp.1 & 37 \\
\hline $\mathrm{Br} 2$ & Brachymyrmex sp.2 & 3 \\
\hline $\mathrm{Ca} 1$ & Camponotus sp. 1 & 2 \\
\hline $\mathrm{Ca} 2$ & Camponotus sp.2 & 2 \\
\hline $\mathrm{Ca} 3$ & Camponotus sp.3 & 5 \\
\hline $\mathrm{Cbr}$ & Centromymex brachycola & 4 \\
\hline Cne & Crematogaster negripliosa & 2 \\
\hline $\mathrm{Ccu}$ & Crematogaster curvispinosa & 4 \\
\hline Cfo & Crematogaster foliocrypta & 2 \\
\hline Clo & Crematogaster longispina & 5 \\
\hline Cni & Crematogaster nigropilosa & 12 \\
\hline Cob & Crematogaster obscurata & 2 \\
\hline Cro & Crematogaster rochai & 7 \\
\hline Cri & Cyphomyrmex rimosus & 3 \\
\hline Dbi & Dolichoderus bispinosus & 3 \\
\hline Dgo & Dorymyrmex goeldii & 2 \\
\hline Ebr & Ectatomma brunneum & 7 \\
\hline Eru & Ectatomma ruidum & 14 \\
\hline Etu & Ectatomma tuberculatum & 2 \\
\hline $\mathrm{Hpu}$ & Hypoponera punctaticeps & 3 \\
\hline Hcr & Hypoponera creola & 18 \\
\hline Hop & Hypoponera opacior & 16 \\
\hline Hpn & Hypoponera punctatisima & 2 \\
\hline Hy2 & Hypoponera sp.2 & 2 \\
\hline Lpr & Labidus praedator & 2 \\
\hline $\mathrm{Mph}$ & Monomorium pharaonis & 3 \\
\hline $\mathrm{Npu}$ & Neivamyrmex punctaticeps & 3 \\
\hline $\mathrm{Nfu}$ & Nylanderia fulva & 19 \\
\hline Oyu & Odontomacus yucatecus & 2 \\
\hline Par & Pachycondyla arhuaca & 1 \\
\hline Pa1 & Pachycondyla sp.1 & 3 \\
\hline Plo & Paratrechina longicornis & 4 \\
\hline Pco & Pheidole cocciphaga & 4 \\
\hline Pin & Pheidole inversa & 9 \\
\hline Psc & Pheidole scalaris & 4 \\
\hline $\mathrm{Ph} 1$ & Pheidole sp.1 & 10 \\
\hline
\end{tabular}




\begin{tabular}{|c|c|c|}
\hline $\mathrm{Ph} 2$ & Pheidole sp.2 & 2 \\
\hline $\mathrm{Ph} 3$ & Pheidole sp.3 & 2 \\
\hline $\mathrm{Ph} 4$ & Pheidole sp.4 & 3 \\
\hline Psu & Pheidole subarmata & 20 \\
\hline Pva & Pheidole vallifica & 4 \\
\hline $\operatorname{Pg} 1$ & Pseudomyrmex gracilis sp.1 & 2 \\
\hline $\operatorname{Pg} 2$ & Pseudomyrmex gracilis sp. 2 & 2 \\
\hline $\operatorname{Pg} 5$ & Pseudomyrmex gracilis sp.5 & 2 \\
\hline Pc1 & Pseudomyrmex occulatus sp.1 & 2 \\
\hline Ppa & Pseudomyrmex pallens & 3 \\
\hline Pse 1 & Pseudomyrmex sp.1 & 11 \\
\hline Sge & Solenopsis geminata & 7 \\
\hline Spi & Solenopsis picea & 4 \\
\hline So1 & Solenopsis sp.1 & 3 \\
\hline So2 & Solenopsis sp.2 & 3 \\
\hline So3 & Solenopsis sp. 3 & 2 \\
\hline So4 & Solenopsis sp.4 & 2 \\
\hline Tgi & Tranopelta gilva & 4 \\
\hline Ty1 & Typhlomyrmex sp.1 & 2 \\
\hline Wau & Wasmannia auropunctata & 4 \\
\hline
\end{tabular}


Appendix 2. List of termite species used in the analysis. Only species that appeared in 2 or more samples were kept. The last column (\#samples) gives the number of samples in which each termite specie appeared from a total of 75 samples.

\begin{tabular}{clc}
\hline Species code & Species & \# samples \\
\hline An3 & Anoplotermes sp. 1 & 34 \\
An4 & Anoplotermes sp. 4 & 14 \\
Gr1 & Grigiotermes sp. 1 & 33 \\
Gr2 & Grigiotermes sp. 27 \\
Hte & Heterotermes tenius & 27 \\
Na2 & Nasutitermes sp. 2 & 6 \\
Nta & Neocapritermes talpa & 3 \\
Ntp & Neocapritermes talpoides & 2 \\
Sym & Syntermes molestus & 10 \\
Te1 & Termes sp. 1 & 5 \\
\hline
\end{tabular}




\section{Figures}

Fig.1. Between-group analysis on the physical soil properties with land use (a) or region (b). Top: projection of data set variability plotted on a factorial map of the first two discriminating axis according to respective factor. Labels on the gravity center correspond to sub-factor of respective factor. Bottom: correlation circles plot with variable vectors (for codes, see Table 1) for each respective factor. (a) Land uses: IP. Improved Pasture, S. Savanna, OP: Oil Palm plantation, AC. Annual Crop, R: Rubber plantation. Eigen values $76.82 \%, 16.69 \%$ for axes 1 to 2 respectively. Randtest: simulated p-value: 0.001. Explained variance: 17.42\%. (b) Regions: PL: Puerto López, PG: Puerto Gaitán, CAR: Carimagua. Eigen values $78.48 \%, 21.24 \%$ for axes 1 to 2 respectively. Randtest: simulated p-value: 0.01. Explained variance: $8.04 \%$.

a) Effect of land use
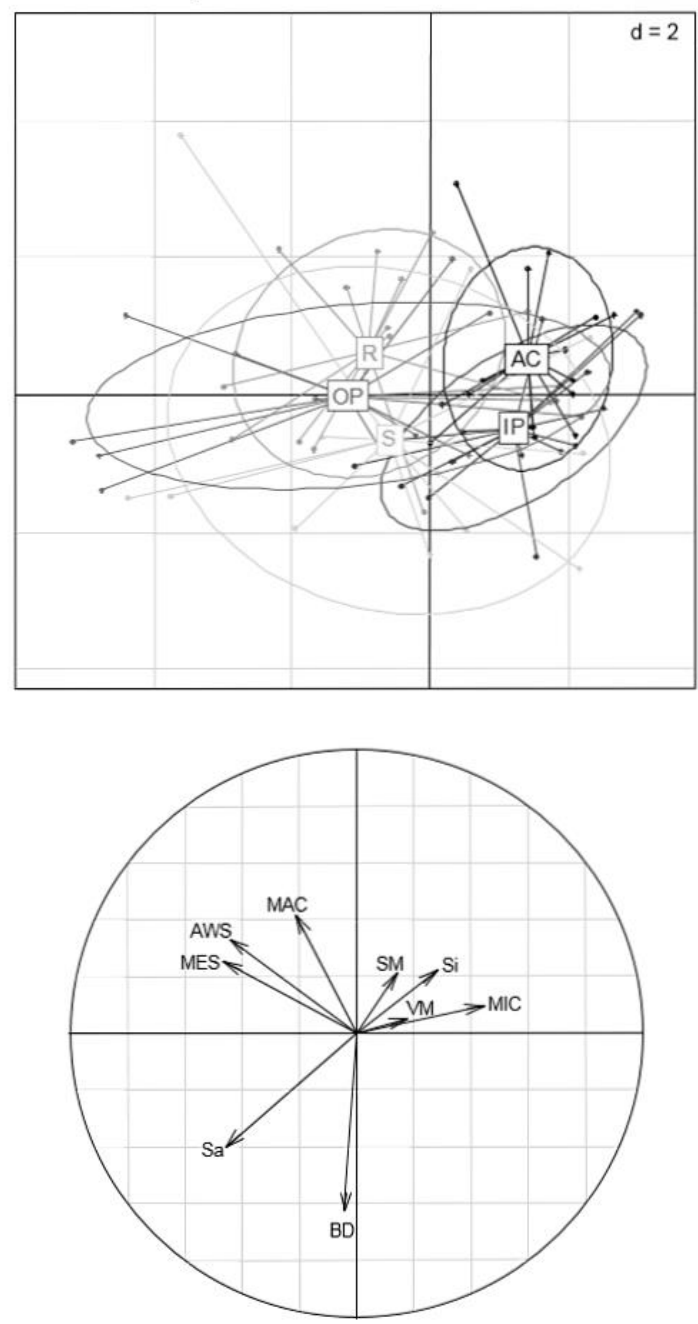

b) Effect of region

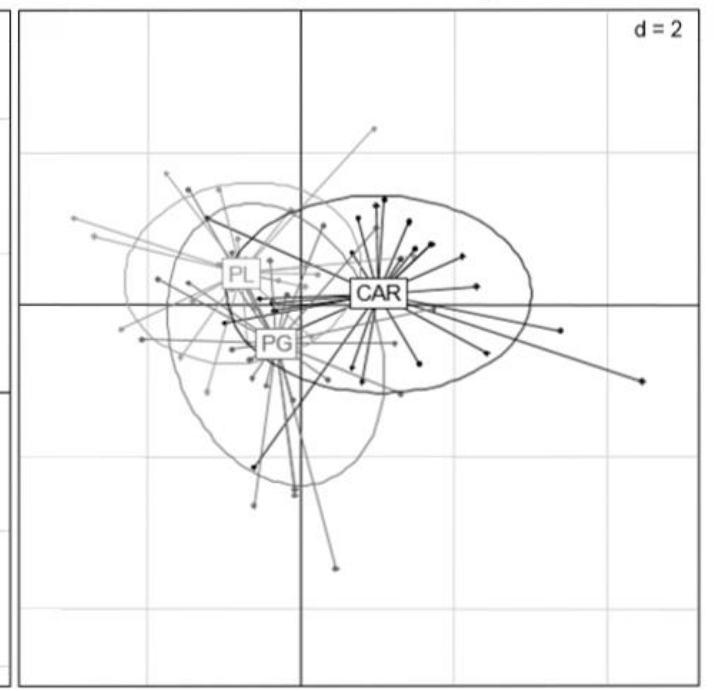


Fig. 2. Between-group analysis on the chemical soil properties with land use (a) or region (b) factor. Top: projection of data set variability plotted on a factorial map of the first two discriminating axis according to respective factor. Labels on the gravity center correspond to sub-factor of respective factor. Bottom: correlation circles plot with variable vectors (for codes, see Table 1) for each respective factor. (a) Land uses: IP. Improved Pasture, S. Savanna, OP: Oil Palm plantation, AC. Annual Crop, R: Rubber plantation. Eigen values $84.90 \%, 11.38 \%$ for axes 1 to 2 respectively. Randtest: simulated p-value: 0.001 . Explained variance: $27.87 \%$. (b) Regions: PL: Puerto López, PG: Puerto Gaitán, CAR: Carimagua. Eigen values $69.81 \%, 30.19 \%$ for axes 1 to 2 respectively. Randtest: simulated p-value: 0.034. Explained variance: $5.49 \%$.

a) Effect of land use
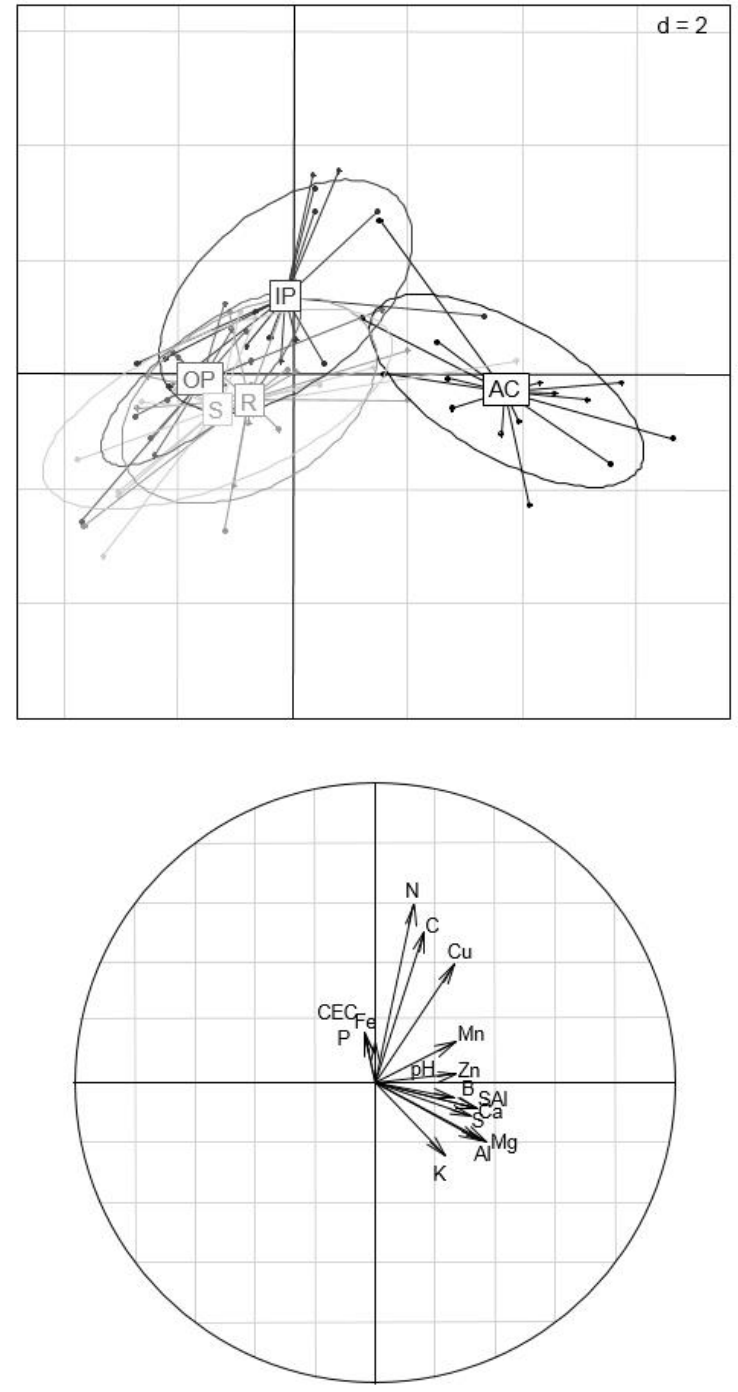

b) Effect of region

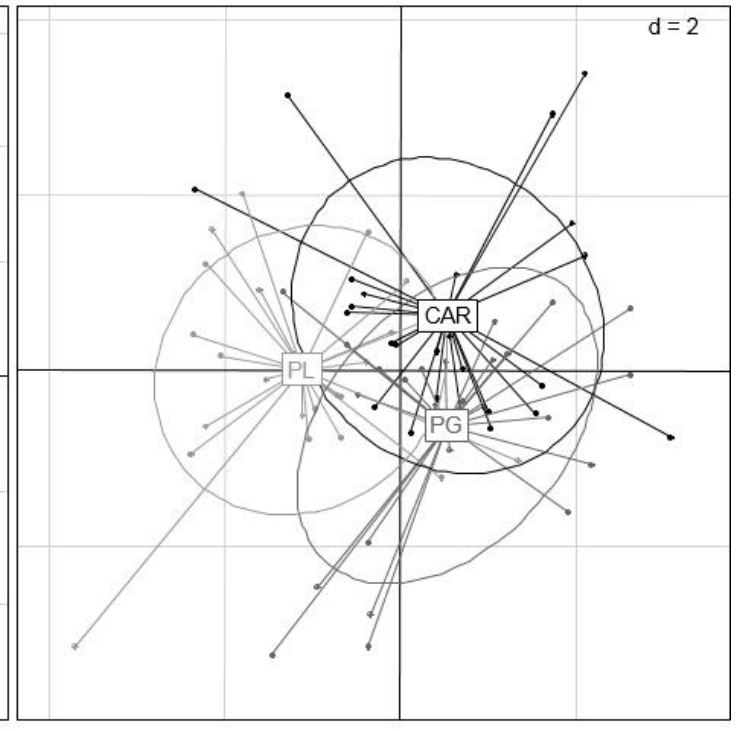


Fig. 3. Between-group analysis on the termite communities with land use factor (no effect were found for the region factor). Top: projection of data set variability plotted on a factorial map of the first two discriminating axis according to land use factor. Labels on the gravity center correspond to sub-factor of land use. Bottom: correlation circles plot with variable vectors (for codes, see Appendix 2). Land uses: IP. Improved Pasture, S. Savanna, OP: Oil Palm plantation, AC. Annual Crop, R: Rubber plantation. Eigen values $58.44 \%, 11.38 \%$ for axes 1 to 2 respectively. Randtest: simulated p-value: 0.028 . Explained variance: 10.32 .

a) Effect of land use

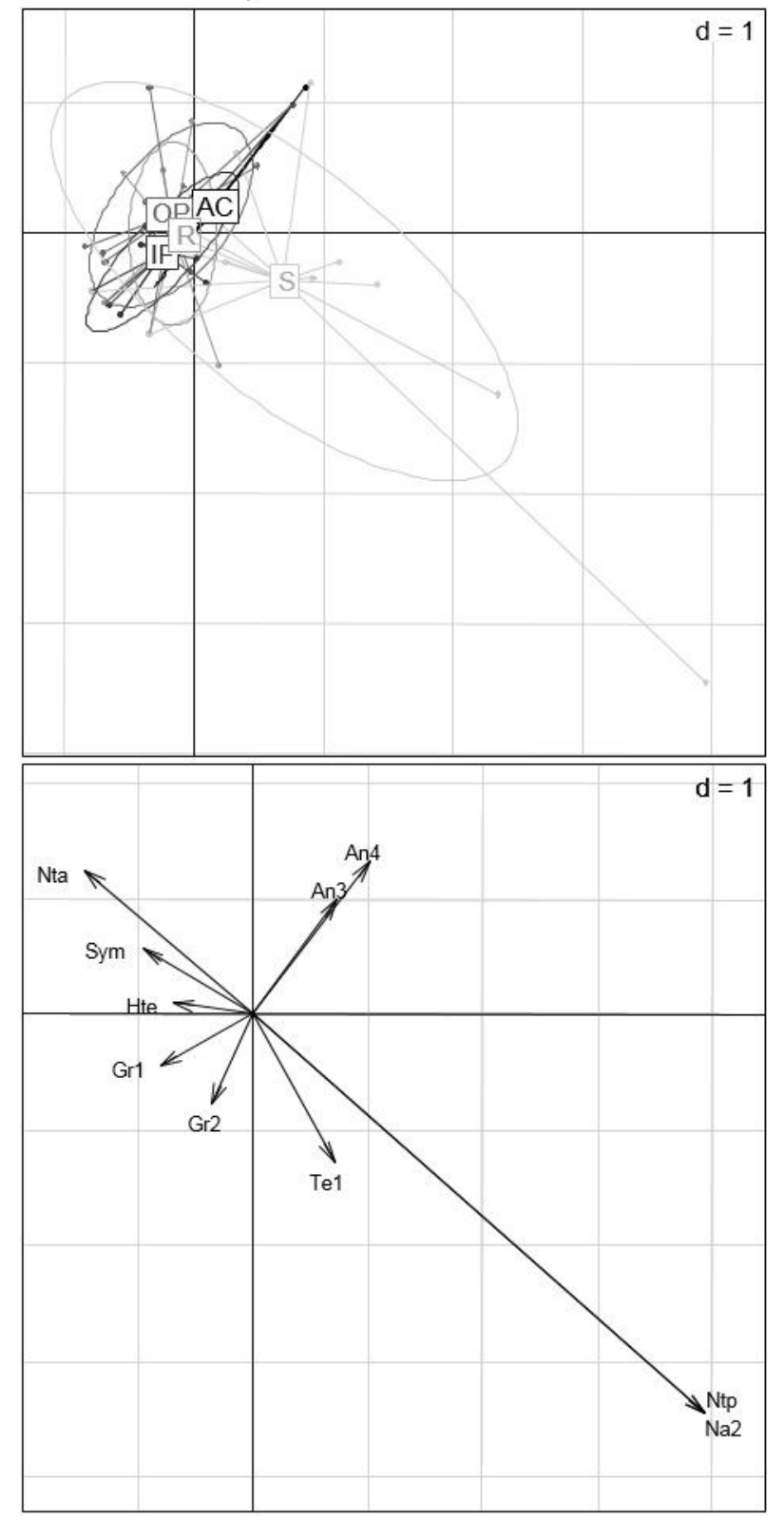


Fig. 4. Between-group analysis on ant communities with land use (a) or region (b) factor. Top: projection of data set variability plotted on a factorial map of the first two discriminating axis according to respective factor. Labels on the gravity center correspond to sub-factor of respective factor. Bottom: correlation circles plot with variable vectors (for codes, see Appendix 1) for each respective factor. (a) Land uses: IP. Improved Pasture, S. Savanna, OP: Oil Palm plantation, AC. Annual Crop, R: Rubber plantation. Eigen values $34.81 \%, 29.76 \%$ for axes 1 to 2 respectively. Randtest: simulated p-value: 0.032. Explained variance: 6.93\%. (b) Regions: PL: Puerto López, PG: Puerto Gaitán, CAR: Carimagua. Eigen values $56.41 \%, 43.59 \%$ for axes 1 to 2 respectively. Randtest: simulated p-value: 0.001. Explained variance: $4.46 \%$.

a) Effect of land use

b) Effect of region

(1)

